\title{
Deborah K. Palmer, Teacher Leadership for Social Change in Bilingual and Bicultural Education, Multilingual Matters, Bristol, UK \& Blue Ridge Summit, PA 2018, pp. 198
}

Minoritized students (Bishop, 2013) in the current sociopolitically-conservative context face intense scrutiny, hostility, and oppressive rhetoric. This is especially true for immigrants or refugees who experience a negative context of reception (Stepick \& Stepick, 2009) from the US through racist and anti-immigrant sentiment that has become acceptable under the United States (US) Trump administration. At the same time, across the US the number of culturally and linguistically diverse students continues to rise, and about one in four students in the US currently speaks a language other than English at home (US Census Bureau, 2015). What can teachers, educators, and teacher educators do to re-construct educational programs that are grounded in social justice, critical consciousness (Freire, 1970), love, and hope?

The author of this eight-chapter book, Dr Deborah Palmer, provides a researchbased framework with answers to that question. Palmer is a well-known professor in the field of bilingual and bicultural education who works in Educational Equity and Cultural Diversity in the School of Education at the University of Colorado, Boulder. Palmer is a former faculty member of the University of Texas, Austin in Bilingual/Bicultural Education and has conducted extensive international work in Mexico and Guatemala. Palmer's research agenda explores a broad variety of issues related to bilingual and bicultural education, such as language policy and

1 School of Teaching and Learning, University of Florida, Gainesville, FL, USA. E-MAIL: mcoady@coe.ufl.eduｏrCID: 0000-0002-1088-7392

2 School of Teaching and Learning, University of Florida, Gainesville, FL, USA. E-MAIL: aolszewska@ufl.edu ORCID: 0000-0001-7060-4844 
politics, race and social class, and creating equitable spaces for linguistically and culturally diverse students and the teachers who work with them.

Palmer's recently published book, Teacher Leadership for Social Change in Bilingual and Bicultural Education, is the fruit of her work, Proyecto Maestría (2007-2013), under a US Department of Education, Office of English Language Acquisition (OELA) National Professional Development project.

The aim of Palmer's book is to define and examine "bilingual teacher leadership", a theoretically informed construct that combines prior scholarship on teacher leadership and bilingual teacher education. In this construct, Palmer prompts the reader to consider more comprehensive and multilayered identities of a bilingual teacher leader and the transformative work of a bilingual teacher leader, one that leads to social justice and transformation. Palmer's guiding question was what does teacher leadership "mean for bilingual teachers as they claim new identities through the empowering space of a university cohort-based degree program?” (p. 6). This question drives the study and narrative of the book, and Palmer interweaves responses to the question using participating teachers' voices. As a result, Palmer attempts to inspire other teacher educators, practitioners, and school communities "to better understand what is necessary, and what is possible" (p. 2) by sharing stories of Proyecto Maestría teachers.

The book is organized in eight chapters. The first chapter, titled 'Why bilingual teacher leadership?', provides the reader with the history, background, and rationale for Palmer's bilingual teacher education program at the University of Texas, Austin. In addition, it reveals what inspired and urged Palmer to conduct the study and write the book. The author also describes the sociohistoric and demographic context of Central Texas, with a focus on the dynamic nature of language policies and bilingual education in this US-Mexico border state. It is noteworthy that Texas is one of the most culturally and linguistically diverse regions in the US with a large emergent bilingual (EB) student population that represents approximately $18.5 \%$ of all Texas students. In the introduction of the book, Palmer describes the theoretical underpinnings of her work, using both Bakhtin's (1998) theory of identity co-construction through dialogue and Freire's (2000) theories of dialogue and pedagogy as praxis - reflection and action - which is rooted in love and hope. Finally, an overview of the book is provided in the first chapter.

In the second chapter, the author includes an extensive literature review related to educational leadership, pedagogy devoted to EB students, and critical pedagogies in the context of bilingual education. This section of the book reveals that despite the significant number of studies conducted on teacher leadership and bilingual education, there remains a dearth of literature that addresses the con- 
struct 'bilingual teacher leadership'. In this chapter, Palmer attempts to illustrate this complex construct by bringing together these two areas and by identifying the key program elements that transform education for EB students. She argues for reflexive spaces for bilingual teachers who become leaders, change agents, and advocates for EB students. Palmer also defines the characteristics of successful critically-engaged bilingual teacher leaders.

Chapter 3, titled 'Developing teacher agency and identity in bilingual and bicultural educational contexts: Critical pedagogies for hope and transformation', provides a theoretical framework underpinning this study. Using Bakhtin's concepts of 'dialogue', 'authoring', and 'identity development', as well as Freire's dialogue as praxis, the author brings together constructs that align theory and scholarly research to bilingual teacher leaders' identities. In this chapter, Palmer theorizes that a holistic perspective towards identity, and embracing sociocultural and linguistic diversity, advocacy, and professionalism, may be a more adequate approach to framing bilingual teacher leaders' identities. Some dimensions of the 'bilingual teacher leadership' construct include critical reflection as action in the classroom, the co-construction of teachers' own linguistic and cultural identities, engagement in collective professional work, building professional communities of practice, and self-authoring. The final practice, self-authoring, reaffirms and deepens the work of bilingual teacher leaders as activists, advocates, and agents of change. Palmer argues that in following such a model, schools are sites of possibility and become transformative spaces.

The fourth chapter describes the project participant recruitment process and introduces the 53 teachers enrolled in Proyecto Maestría program. This section also discusses the background of the study, its methodology, data collected, and the evolution of the program over the six year period. In this chapter, Palmer provides a detailed overview of the 15-month Master's degree program in which the teachers participated. The coursework in particular would be of interest to teacher educators who work in similar educational context in the US or to those who wish to build teacher leaders in their international contexts.

The subsequent three chapters represent the data analysis conducted by Palmer and the themes that emerged from her analysis. In the fifth chapter, titled 'Bilingual teachers leaders are reflexive practitioners', the author sheds light on the process that the project participants underwent in the co-construction of their identities as change agents, bilingual student advocates, and leaders. The teachers in Proyecto Maestría continuously reflected on their teaching and prior experiences and were exposed to theories of educational praxis, which aimed to generate new knowledge. An important component of this chapter is the power of teacher 
action research, which empowered the teachers through the process of critically engaged reflection and learning.

The title of chapter 6, 'Bilingual teacher leaders are cultural/linguistic brokers', illuminates the main theme of this section. Palmer draws the audience's attention to the connection between professionalism and the cultural and linguistic identities of teachers. She views teachers' self-exploration of their cultural and linguistic identities as fundamental to the bilingual teacher leadership through the program. The process was facilitated by an array of course assignments that guided teachers through a process of self-interrogation. In this chapter, the reader will find a richness of participants' personal cultural and linguistic stories, told through a translanguaging narrative, which is embroidered in Spanish and English. Their stories portray teachers' deeper insights into their identities and, eventually, transformation into responsible bilingual teacher leaders and advocates of EB students.

The penultimate chapter of the book titled, 'Bilingual teacher leaders are collaborators', focuses on the community factor in becoming a bilingual teacher leader. As educators who teach EB students frequently find themselves marginalized and in oppressive systems, having a safe group of colleagues and allies who are willing to collaborate, engage in a dialogic relationship, and share resources supports teachers' in their journeys. The study shows that the project participants remained in close professional and personal relationship during and after the program's completion. The value of community, rooted in the Bakhtinian and Freirean traditions, supported bilingual teacher leaders identity co-construction.

In the book's final chapter, Palmer concludes with a theoretically-informed and research-based definition of 'bilingual teacher leadership'. She frames critical multicultural awareness and advocacy as essential in teachers' reflexive practice, collaboration, and cultural and linguistic identity self-awareness. These features allows for the creation of transformative educational spaces for bilingual teachers' empowerment and leadership. Ultimately, Palmer concedes that teaching is a political act that should lead others toward change and transformation. Finally, the author provides readers with suggestions for educational stakeholders, including higher institution educators, practitioners, scholars, and legislators.

This book constitutes the author's personal fight for and testimony of transformation and social justice in critical times in the US through bilingual teacher leadership and advocacy. The book is a representation of hope for all of those who are inspired by love, equity, and who respond to the urgent call for social justice. Palmer's book ends with the spirit of hope, which is captured in its opening poem, XXXII, by Emily Dickinson (1924): 
Hope is the thing with feathers -

That perches in the soul -

And sings the tune without the words -

And never stops - at all -

\section{References}

Bishop, R. (2013). Indigenous and Other Minoritized Students. In: J. Hattie \& A.M. Anderman (Eds.), International Guide to Student Achievement (pp. 74-76). New York, NY: Routledge.

Freire, P. (1970). Pedagogy of the Oppressed. Trans. Myra Bergman Ramos. New York, NY: Continuum.

Stepick, A., \& Stepick, C.D. (2009). Diverse Contexts of Reception and Feelings of Belonging. Forum Qualitative Sozialforschung/Forum: Qualitative Social Research, 10(3). DOI: 10.17169/fqs-10.3.1366. 